\title{
The Tromsø study: physical fitness, self reported physical activity, and their relationship to other coronary risk factors
}

\author{
Maja-Lisa Løchen, Knut Rasmussen
}

\begin{abstract}
Study objective-The aim was to investigate the associations between physical fitness, leisure physical activity, and coronary risk factors.

Design-This was a cross sectional study of a random sample of men and women, following a population survey.

Setting-The municipality of Tromse, Norway in 1986-1987.

Participants-All men born 1925-1966 and all women born 1930-1966 were invited to the survey; 21826 subjects attended $(81 \%$ of the eligible population): of these, 297 men and 312 women, randomly selected, attended the present study (attendance rates $94 \%$ in men and $89 \%$ in women).

Measurements and main results-Fitness was tested by bicycle ergometry. Physical activity was reported on a questionnaire. Multiple regression analysis was performed with fitness and leisure activity as dependent variables, and coronary risk factors as independent variables. Fitness and leisure activity were positively related $(p<0.05)$. Prominent findings for fitness were negative associations with age and smoking $(p<0.05)$, and positive associations with body mass index in both sexes $(p<0.01)$. HDL cholesterol and systolic blood pressure were significant predictors of fitness in men $(p<0.01)$. Smoking emerged as a strong negative predictor for leisure activity in women $(p<0.01)$, and a negative relation between leisure activity and total cholesterol was found in men $(\mathbf{p}<0.01)$.

Conclusions-The study indicates that coronary risk factors are more closely linked to physical fitness than to leisure physical activity.
\end{abstract}

Institute of

Community Medicine, University of Tromse, N-9000 Tromse,

Norway

M-L Løchen

Department of

Medicine, Institute of

Clinical Medicine,

University of Tromse,

Norway

K Rasmussen

Correspondence to:

Dr Løchen

Accepted for publication June 1991
The epidemiological evidence linking either objectively measured physical fitness or subjective reports on physical activity to risk of coronary heart disease is abundant but inconclusive. ${ }^{1-11}$ One unsolved problem concerns to what extent the cardiovascular risk is related to fitness as such or to the accompanying levels of physical activity. Another is whether the physical fitness factor and the level of physical activity act directly or through concomitant variation in other known coronary risk factors. ${ }^{12-19}$ Few epidemiological studies involve simultaneous assessments of objectively measured physical capacity as well as subjective reports on habitual physical activity. The present report aims at studying cross sectionally both the physical performance and the self reported physical activity levels in the same population, their intercorrelations and the associations with other coronary heart disease risk factors.

\section{Methods}

In $1986-87,28847$ subjects were invited to take part in a health survey in the municipality of Tromsø. This included all men born between 1925 and 1966, and all women born between 1930 and 1966. Among the invited subjects, 49 were dead, 1600 had moved, and 583 were temporarily living outside Tromsø during the screening period, giving 26615 as the eligible population; of these, 21826 subjects attended the screening (179 without invitation), giving an attendance rate of $81.3 \%$ of the eligible population. The screening programme started August 1986 and was finished April 1987. Enclosed with the letter of invitation was a questionnaire covering among others the following aspects: previous cardiovascular disease, physical activity at work and in leisure time, and smoking habits. The participants were asked to fill in the questionnaire at home and return it at the examination. This questionnaire was almost identical to those used in the former studies in Tromsø. ${ }^{2021}$ The examination comprised checking the questionnaire for inconsistency, measurements of weight, height, and blood pressure, and the collection of venous non-fasting blood samples for measurements of blood lipids.

Total cholesterol and triglycerides were analysed in fresh serum by enzymatic colorimetric methods with commercial kits (CHOD-PAP, Boehringer Mannheim, for cholesterol, and GPO-PAP, Boehringer Mannheim, for triglycerides). High density lipoprotein (HDL) cholesterol was determined after precipitating serum with $\mathrm{MgCl}_{2}$. The laboratory analyses were performed by the Division of Clinical Chemistry, University Hospital of Tromsø.

In the questionnaire, physical activity in leisure time was graded from I to IV according to which of the following categories could best describe the participants' level of physical activity: Grade I: reading, watching television, or activities which do not need physical activity; Grade II: walking, cycling, or some other form of physical activity for at least $4 \mathrm{~h}$ per week; Grade III: exercises to keep fit, heavy gardening, etc, for at least $4 \mathrm{~h}$ per week; Grade IV: hard training or participation in competitive sports, regularly and several times a week. If leisure activity varied between summer 
and winter, the person was asked to state the average.

Physical activity at work was graded from I to IV according to the following categories: $I=$ mostly sedentary work, II = work leading to much walking, III = work leading to much walking and lifting, IV = heavy manual labour. The questions on physical activity in this study have been widely used in different Scandinavian studies, since they were first described in 1968, and they have been extensively validated. ${ }^{22-25}$

In the analyses, physical activity categories III and IV were merged both in leisure and at work since there were very few subjects in category IV.

The present study constitutes a random subsample of those attending the screening. Invitation was sent by mail 2-6 weeks after the initial screening to 316 men and 350 women who were randomly selected from the screened population; 297 men and 312 women attended the survey, giving attendance rates of $94 \%$ and $89 \%$ in men and women, respectively.

Four women and one man were unable to perform the exercise test because of disabilities in the musculoskeletal system. One woman and eight men with previous myocardial infarction were included in the study.

The examinations were performed from October 1986 to June 1987. The examination consisted of a history of previous disease, a 12 lead resting electrocardiogram and an exercise test. Physical working capacity was measured with a graded submaximal or maximal bicycle exercise test with a pedalling frequency of $60 / \mathrm{min}$. The initial work load was set at $25 \mathrm{~W}$, with $25 \mathrm{~W}$ increments every minute up to a maximum of 250 W (10 minutes). The tests were interrupted prematurely when symptoms such as angina pectoris, dyspnoea, or exhaustion made this necessary. No complications were noted during the exercise tests. Physical fitness was defined as the maximum work load (watts) performed.

Because of missing data, the number of subjects included in the individual analyses varies.

Table I Levels of physical fitness and moderate/heavy physical activity in leisure and at work according to age.

\begin{tabular}{|c|c|c|c|c|c|c|c|c|c|c|}
\hline \multirow[b]{3}{*}{$\begin{array}{l}\text { Age } \\
\text { (years) }\end{array}$} & \multicolumn{5}{|l|}{ Men } & \multicolumn{5}{|c|}{ Women } \\
\hline & & \multirow{2}{*}{\multicolumn{2}{|c|}{$\begin{array}{l}\text { Fitness } \\
\text { (watts) } \\
\text { Mean (SD) }\end{array}$}} & \multicolumn{2}{|l|}{ Activity } & \multirow{3}{*}{\begin{tabular}{c}
\multicolumn{1}{l}{$n$} \\
50 \\
98 \\
95 \\
65
\end{tabular}} & \multirow{2}{*}{\multicolumn{2}{|c|}{$\begin{array}{l}\text { Fitness } \\
\text { (watts) } \\
\text { Mean (SD) }\end{array}$}} & \multicolumn{2}{|l|}{ Activity } \\
\hline & & & & \multirow{2}{*}{$\begin{array}{l}\begin{array}{l}\text { Leisure } \\
(\%)\end{array} \\
41.5 \\
34.1 \\
24.1 \\
21.2 \\
5.9\end{array}$} & \multirow{2}{*}{$\begin{array}{l}\begin{array}{l}\text { Work } \\
(\%)\end{array} \\
51 \cdot 2 \\
25 \cdot 6 \\
16 \cdot 1 \\
21 \cdot 2 \\
35 \cdot 3\end{array}$} & & & & $\begin{array}{l}\text { Leisure } \\
(\%)\end{array}$ & $\begin{array}{l}\text { Work } \\
(\%)\end{array}$ \\
\hline $\begin{array}{l}20-9 \\
30-9 \\
40-9 \\
50-9 \\
60-1\end{array}$ & $\begin{array}{l}41 \\
82 \\
87 \\
66 \\
17\end{array}$ & $\begin{array}{l}249 \cdot 4 \\
243 \cdot 3 \\
238 \cdot 2 \\
195 \cdot 1 \\
182 \cdot 4\end{array}$ & $\begin{array}{c}(3.9) \\
(16.2) \\
(26.1) \\
(57.6) \\
(53.6)\end{array}$ & & & & $\begin{array}{l}169 \cdot 0 \\
164 \cdot 8 \\
167 \cdot 1 \\
140 \cdot 4\end{array}$ & $\begin{array}{l}(41 \cdot 5) \\
(35.7) \\
(38.6) \\
(35.0)\end{array}$ & $\begin{array}{r}10 \cdot 0 \\
12 \cdot 2 \\
8.4 \\
3 \cdot 1\end{array}$ & $\begin{array}{l}26.0 \\
15.3 \\
15.8 \\
16.9\end{array}$ \\
\hline $\begin{array}{l}20-59 \\
20-61\end{array}$ & $\begin{array}{l}276 \\
293\end{array}$ & $\begin{array}{l}231 \cdot 1 \\
228 \cdot 2\end{array}$ & $\begin{array}{l}(38 \cdot 7) \\
(41 \cdot 2)\end{array}$ & $\begin{array}{l}29 \cdot 0 \\
27 \cdot 6\end{array}$ & $\begin{array}{l}25.4 \\
25.9\end{array}$ & 308 & 161.0 & $(38.8)$ & $8 \cdot 8$ & 17.5 \\
\hline
\end{tabular}

STATISTICAL ANALYSIS

SAS (Statistical Analysis System) ${ }^{26}$ was used in the statistical analyses. Two way analysis of covariance were performed to test for linear trend of fitness according to activity at leisure and at work. To determine the age adjusted coronary risk factors, analysis of covariance was used. Age adjusted correlation coefficients were determined for combinations of physical fitness and leisure physical activity with the coronary risk factors. Multiple linear regression analyses were performed to estimate the partial impact of coronary risk factors as independent variables on the dependent variables physical fitness and physical activity at leisure.

\section{Results}

\section{SUBJECT CHARACTERISTICS}

Fitness and activity levels of the study population are presented in table I. The mean physical fitness in the age group 20-59 years was higher in men $(231 \mathrm{~W})$ than in women $(161 \mathrm{~W})(\mathrm{p}<0.0001)$. In men, fitness generally decreased with age. In women, the trend was not so clear, as there was a tendency for better fitness in the age group 40-49 years than in the younger age group. However, the age trend was signified for each sex separately $(\mathrm{p}<0.0001)$.

High and moderate physical activity in leisure time was considerably more common in men $(29 \%)$ than in women $(9 \%)(p<0.001)$. For women, there were no significant differences in physical activity in leisure time between the age groups below 50 years. In men, leisure time physical activity in general decreased with age $(\mathrm{p}<0.05)$

At work, women were less physically active than men $(18 \%$ versus $25 \%$ ), and the difference between the sexes was significant $(p<0.01)$. Only in men was a significant difference in physical activity at work present between the age groups, the youngest and the oldest being the most active. However, this finding is based upon small numbers in the oldest age group (17 men).

Conventional coronary risk factors as well as their correlations with fitness and leisure activity are shown in table II. The table indicates that a number of significant relations between the fitness level and the risk factors were present. Important observations were the significant associations between fitness level and total cholesterol $(p<0.05)$, triglycerides $(p<0.05)$, heart rate $(p<0.001)$, and smoking $(p<0.001)$ in both sexes. HDL cholesterol and systolic blood pressure (both $p<0.001$ ) in men and body mass index in women $(p<0.01)$ were also significantly related to fitness.
Table II Age adjusted means of coronary risk factors and their correlation with physical fitness and physical activity in leisure.

\begin{tabular}{|c|c|c|c|c|c|c|c|c|}
\hline & \multicolumn{4}{|c|}{$\begin{array}{l}\text { Men } \\
(n=292)\end{array}$} & \multicolumn{4}{|c|}{$\begin{array}{l}\text { Women } \\
(n=308)\end{array}$} \\
\hline & \multirow[b]{2}{*}{ Mean } & \multirow[b]{2}{*}{$(S D)$} & \multicolumn{2}{|c|}{ Correlation with } & \multirow[b]{2}{*}{ Mean } & \multirow[b]{2}{*}{$(S D)$} & \multicolumn{2}{|c|}{ Correlation with } \\
\hline & & & $\begin{array}{l}\text { Fitness } \\
r\end{array}$ & $\begin{array}{l}\text { Activity } \\
r\end{array}$ & & & $\begin{array}{l}\text { Fitness } \\
r\end{array}$ & $\begin{array}{l}\text { Activity } \\
r\end{array}$ \\
\hline $\begin{array}{l}\text { Cholesterol (mmol/litre) } \\
\text { HDL cholesterol (mmol/litre) } \\
\text { Triglycerides (mmol/litre) } \\
\text { Body mass index }\left(\mathrm{kg} / \mathrm{m}^{2}\right) \\
\text { Systolic blood pressure }(\mathrm{mm} \mathrm{Hg}) \\
\text { Heart rate (beats/min) } \\
\text { Daily smoking }(\%)\end{array}$ & $\begin{array}{r}5.90 \\
1.40 \\
1.57 \\
2.47 \\
130.9 \\
71 \cdot 8 \\
44 \cdot 2\end{array}$ & $\begin{array}{l}(1 \cdot 24) \\
(0.36) \\
(0.95) \\
(0.29) \\
(15 \cdot 6) \\
(12.0)\end{array}$ & $\begin{aligned}-0 \cdot 142 \star \\
0.205 \ddagger \\
-0 \cdot 206 \ddagger \\
0 \cdot 050 \\
-0 \cdot 213 \ddagger \\
-0 \cdot 203 \ddagger \\
-0 \cdot 296 \ddagger\end{aligned}$ & $\begin{array}{l}-0 \cdot 183 \dagger \\
0.086 \\
-0.070 \\
-0.098 \\
-0.021 \\
-0 \cdot 102 \\
-0.146 \star\end{array}$ & $\begin{array}{r}5 \cdot 82 \\
1 \cdot 68 \\
1 \cdot 10 \\
2 \cdot 32 \\
120 \cdot 2 \\
76 \cdot 3 \\
43 \cdot 8\end{array}$ & $\begin{array}{l}(1.32) \\
(0.38) \\
(0.56) \\
(0.30) \\
(16.5) \\
(12.5)\end{array}$ & $\begin{array}{l}-0 \cdot 143^{\star} \\
0 \cdot 065 \\
-0 \cdot 146^{\star} \\
0 \cdot 158 \dagger \\
-0 \cdot 104 \\
-0 \cdot 185 \ddagger \\
-0 \cdot 210 \ddagger\end{array}$ & $\begin{array}{l}-0.033 \\
0.0235 \\
0.002 \\
0.066 \\
0.001 \\
-0.169 \dagger \\
-0.218 \dagger\end{array}$ \\
\hline
\end{tabular}

${ }^{\star} \mathrm{p}<0.05 ; \uparrow \mathrm{p}<0.01 ; \neq \mathrm{p}<0.001$ 
Only a small number of risk factors were significantly associated with activity score. Smoking habits showed a significant relation to activity in both sexes $(p<0.05)$, in addition to total cholesterol in men and heart rate in women (both $\mathrm{p}<0.01$ ).

RELATIONSHIPS BETWEEN FITNESS AND ACTIVITY The age adjusted physical fitness by level of physical activity in leisure time and at work is shown in the figure. For both sexes, fitness increased with activity in leisure time $(p<0.001)$, while it decreased with activity at work $(p<0.05)$.

\section{MULTIPLE REGRESSION ANALYSIS}

Tables III and IV give the results of the multiple linear regression analyses with physical fitness and leisure activity, respectively, as the dependent variables. In general, the impression from the univariate analyses was confirmed. For fitness, prominent findings were negative associations with smoking and age and positive associations with physical activity in leisure and at work and body mass index in both sexes. Previous myocardial infarction, HDL cholesterol, and systolic blood pressure were significant predictors of fitness in men. The explained variance varied between 46 and $26 \%$ in men and women respectively. Thus a substantial part of the variation in fitness was explained by the other coronary heart disease factors.

For leisure physical activity, smoking and heart rate emerged as having firm negative associations with activity in women. A negative association between physical activity and total cholesterol was observed in men. The explained variance was $12 \%$ in men and $16 \%$ in women, ie much lower than for fitness.

\section{Discussion}

FITNESS-ACTIVITY RELATIONSHIPS

The assessment both of activity and fitness levels has inherent methodological problems. Activity grading is simple to perform in an epidemiological study, but the grading is crude and both over- and underestimation of activity level must occur. The awareness in the population of the importance of activity may lead to biased reporting.

Testing of fitness is more cumbersome, even in the shortened version used in this study. We used $250 \mathrm{~W}$ as the maximum load, which was found to be too low in many men. The fitness factor might have turned out to be more important if a true maximum exercise test had been performed in all subjects. However, about $95 \%$ of the men exercised to a heart rate exceeding 130 beats $/ \mathrm{min}$. Another crucial methodological factor was the choice of bicycle ergometry which measures external work only and gives an advantage to heavy and large subjects.

As expected, highly significant positive correlations were found between fitness and leisure activity (figure). Still, the correlations were rather poor, with age adjusted correlation coefficients of 0.18 in men and 0.39 in women (data not shown). This may indicate that the fitness factor and the activity factor may be regarded as two different dimensions that carry largely independent information, and cannot

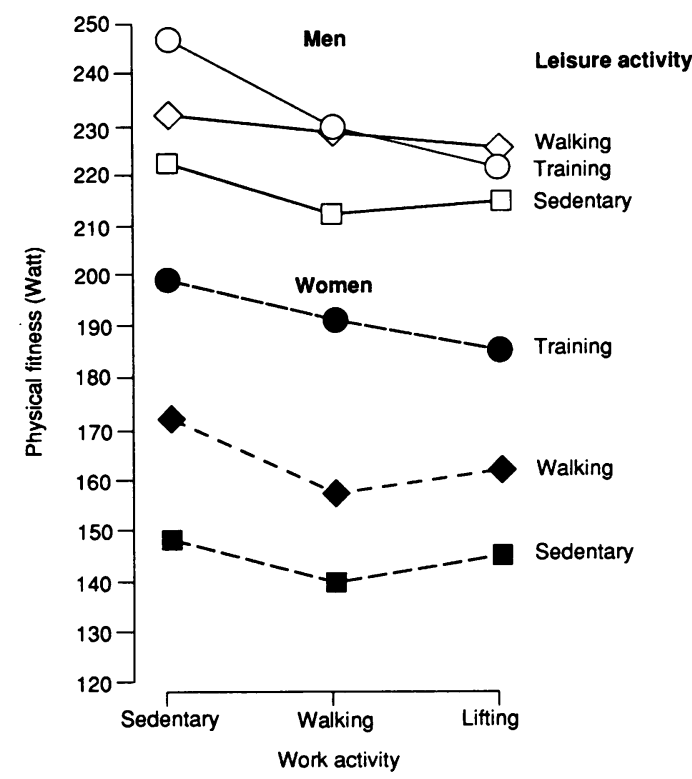

Age adjusted physical fitness (watts) according to physical activity in leisure time and at work. $p<0.001$ for linear trend of fitness by leisure activity in both groups; $p<0.05$ for linear trend of fitness by work activity in both groups.

Table III Multiple regression analysis of physical fitness with several risk factors as independent variables.

\begin{tabular}{|c|c|c|c|c|}
\hline $\begin{array}{l}\text { Fitness mean } \\
R^{2}\end{array}$ & $\begin{array}{l}\text { Men } \\
(n=292) \\
228 \cdot 17 \\
46 \cdot 2^{\circ}{ }_{o}\end{array}$ & & $\begin{array}{l}\text { Women } \\
(n=308) \\
161.04 \\
25.9^{\circ}{ }_{0}\end{array}$ & \\
\hline Variables & $B$ & $p$ & $B$ & $p$ \\
\hline $\begin{array}{l}\text { Infarction } \\
\text { Cholesterol } \\
\text { HDL cholesterol } \\
\text { Triglycerides } \\
\text { Body mass index } \\
\text { Systolic BP } \\
\text { Smoking } \\
\text { Heart rate } \\
\text { Physical activity }\end{array}$ & $\begin{array}{r}-44.509 \\
-1.051 \\
15.344 \\
-3.116 \\
18.973 \\
-0.414 \\
-11.909 \\
-0.197\end{array}$ & $\begin{array}{l}0.0001 \\
0.5555 \\
0.0062 \\
0.1583 \\
0.0078 \\
0.0011 \\
0.0021 \\
0.2263\end{array}$ & $\begin{array}{r}-10 \cdot 135 \\
-3 \cdot 462 \\
4 \cdot 175 \\
-7 \cdot 904 \\
24 \cdot 268 \\
-0 \cdot 193 \\
-8 \cdot 683 \\
-0 \cdot 242\end{array}$ & $\begin{array}{l}0 \cdot 7703 \\
0.0974 \\
0.4795 \\
0.0714 \\
0.0009 \\
0 \cdot 1694 \\
0 \cdot 0384 \\
0 \cdot 1448\end{array}$ \\
\hline $\begin{array}{l}\text { in leisure } \\
\text { at work } \\
\text { Age }\end{array}$ & $\begin{array}{r}5.336 \\
-4.929 \\
-1.916\end{array}$ & $\begin{array}{l}0.0396 \\
0.0104 \\
0.0001\end{array}$ & $\begin{array}{r}19.428 \\
-5.833 \\
-0.644\end{array}$ & $\begin{array}{l}0.0001 \\
0.0341 \\
0.0157\end{array}$ \\
\hline
\end{tabular}

$\mathrm{BP}=$ blood pressure

Table IV Multiple regression analysis of physical activity at leisure with several risk factors as independent variables.

\begin{tabular}{lrlrl}
\hline & $\begin{array}{l}\text { Men } \\
(n=292) \\
12 \cdot 1^{\circ}{ }_{0}\end{array}$ & \multicolumn{3}{c}{$\begin{array}{l}\text { Women } \\
(n=308) \\
16 \cdot 1^{\circ}{ }_{o}\end{array}$} \\
\hline Variables & \multicolumn{1}{c}{$B$} & $P$ & \multicolumn{1}{c}{$B$} & $P$ \\
\hline Infarction & 0.463 & 0.0855 & 0.268 & 0.6211 \\
Cholesterol & -0.109 & 0.0077 & 0.011 & 0.7255 \\
HDL cholesterol & -0.058 & 0.6531 & 0.003 & 0.9773 \\
Triglycerides & 0.040 & 0.4264 & 0.072 & 0.2976 \\
Body mass index & -0.241 & 0.1431 & -0.081 & 0.4835 \\
Systolic BP & 0.002 & 0.3994 & 0.001 & 0.5678 \\
Smoking & -0.170 & 0.0574 & -0.170 & 0.0093 \\
Heart rate & -0.004 & 0.3123 & -0.005 & 0.0367 \\
Physical fitness & 0.003 & 0.0396 & 0.005 & 0.0001 \\
Physical activity & & & & \\
at work & 0.071 & 0.1109 & 0.014 & 0.7483 \\
Age & -0.002 & 0.7096 & 0.005 & 0.2435 \\
\hline
\end{tabular}

$\mathrm{BP}=$ blood pressure

readily be substituted for each other. This also raises the question regarding which of these factors is most important as a predictor of disease.

The fitness-activity relation was stronger in females than in men, which may partly be explained by the test being truly maximal in most females.

Our results confirm previous studies indicating that leisure time activity is the important physical activity factor in a modern, affluent society. ${ }^{2} 27$ 
The negative association between activity at work and fitness may partly be explained by the nature of activity at work, which mostly consists of short bursts of activity which does not give rise to sustained heart rate increase or improve aerobic exercise capacity. In addition, physical activity at work may be regarded as a measure of social class rather than as an indication of activity and fitness level.

\section{RISK FACTORS, ACTIVITY AND FITNESS}

Most of the individual risk factors were more closely associated with fitness than with activity. When all risk factors were included in the multivariate analysis, they accounted for $26-46 \%$ of the variance in objectively measured fitness, while only $12-16 \%$ of the variance in self reported activity was explained. This further supports the argument given above that fitness should be regarded as an independent factor which cannot entirely be explained from the reported activity.

The difference between fitness and activity was particularly noteworthy with regard to blood pressure. While no association between blood pressure and activity was observed, blood pressure and fitness were firmly negatively associated in men. Increased exercise capacity may partially be caused by a lower blood pressure. Both in acute experiments ${ }^{28}$ and in heart failure ${ }^{29}$ it is well established that the impedance to left ventricular ejection is one of the major determinants of stroke volume, and thus physical fitness. It has previously been thought that in the normal individual compensatory factors such as cardiac hypertrophy maintain a constant exercise capacity at high pressure levels. Our present findings may indicate that these compensatory factors are incomplete and that exercise capacity therefore decreases with increasing pressure in normal subjects as well. This result should, however, be interpreted with care, as the relation between fitness and systolic blood pressure was significant in men only, even though women showed the same tendency.

As expected, smoking was negatively related both to fitness and activity. The cause may be twofold; on the one hand smoking may decrease exercise performance; on the other, active persons may be more health concious and thus less likely to smoke.

FITNESS OR ACTIVITY, STRENGTH OR TRAINING? Activity and fitness are commonly regarded as more or less interchangeable: active people get fit. In this study we found the association to be comparatively weak. It would therefore seem fruitful to recall how activity and fitness are related and how they are not.

One difference between the two is with regard to causative factors. While the activity level is influenced by a host of psychological, social, and environmental factors, fitness may primarily be influenced by constitutional, ie, mostly genetic, factors. ${ }^{17}$ Genes linked to fitness may of course also be linked to genes associated with lipids and blood pressure.

In addition to the fact that activity leads to fitness, the opposite may also occur. If you are born with a high physical capacity, you may tend to be more active. The influence on conventional risk factors like lipids, smoking, blood pressure, and obesity is usually thought to take place through the activity factor. Our observation that fitness generally was much more closely linked to the risk factors is therefore remarkable. One explanation may be that fitness was more precisely measured than activity in this study, as discussed above. A more elaborate questionnaire or interview on leisure time physical activity might have given a better estimation and a stronger relation to coronary risk factors than observed. We believe that this is only part of the explanation, and that fitness actually is more closely linked to risk factors. This may be caused by a salutary effect of fitness on risk factors which is not expressed through the activity level. Even more probable is the hypothesis outlined above, that risk factors, in particular smoking and blood pressure, have retroactive effects on fitness, in contrast to activity. Thus fitness may have a bidirectional "benign circle" interrelationship with the risk factors, while the activity effect may be unidirectional.

\section{Conclusion}

From this cross sectional study no conclusions can be drawn with regard to the long term effects of activity and fitness on risk of disease or with regard to effect of changes in lifestyle. That must be left to longitudinal studies. Our study confirms the association between fitness and activity, although the strength of the association was weaker than presumed. It also indicates that coronary risk factors are more closely linked to fitness than to activity. The results indicate that fitness should be added as an important variable in addition to activity in future studies on the relationship between exercise habits and disease.

1 Paffenbarger RS, Hyde RT, Wing AL, Hsieh CC. Physical activity, all-cause mortality, and longevity of college alumni. N Engl f Med 1986; 314: 605-13.

2 Paffenbarger RS, Hyde RT. Exercise in the prevention of coronary heart disease. Prev Med 1984; 13: 3-22.

3 Bruce RA, Hossack KF, DeRouen TA, Hofer V. Enhanced risk assessment for primary coronary heart disease by maximal exercise testing; 10 years experience of Seattle Heart Watch. $\Im$ Am Coll Cardiol 1983; 2: 565-73.

4 Tuomilehto J, Marti B, Salonen JT, Virtala E, Lahti T, Tuomilehto J, Marti B, Salonen JT, Virtala E, Lahti T, to risk factors for coronary heart disease in middle-aged to risk factors for coronary heart disease in

5 Salonen JT, Slater JS, Tuomilehto J, Rauramaa R. Leisure time and occupational physical activity: risk of death from ischemic heart disease. Am $\mathcal{F}$ Epidemiol 1988; 127: 87-94.

6 Cooper KH, Pollock ML, Martin RP, White SR, Linnerud AC, Jackson A. Physical fitness levels vs selected coronary risk factors. $\mathcal{F} A M A$ 1976; 236: 116-69.

7 Erikssen J, Forfang K, Jervell J. Coronary risk factors and physical fitness in healthy middle-aged men. Acta Med Scand 1981; suppl 645: 57-64.

8 Salonen JT, Puska P, Tuomilheto J. Physical activity and risk of myocardial infarcation, cerebal stroke and death. A longitudinal study in Eastern Finland. Am $\mathcal{F}$ Epidemiol 1982; 115: 526-37.

9 LaPorte RE, Adams LL, Savage DD, Brenes G, Dearwater $S$, Cook $T$. The spectrum of physical activity, cardiovascular disease and health: an epidemiologic perspective. Am F Epidemiol 1984; 120: 507-17.

10 Kannel WB, Sorlie P. Some health benefits of physical activity. The Framingham study. Arch Intern Med 1979; 139: 857-61

11 Berlin JA, Colditz GA. A meta-analysis of physical activity in the prevention of coronary heart disease. Am $\mathcal{f}$ Epidemiol 1990 ; 132: 612-28.

12 Ekelund L-G, Haskell WL, Johnson JL, Whaley FS, Criqui MH, Sheps DS. Physical fitness as a predictor of cardiovascular mortality in asymptomatic North American men. The lipid research clinics mortality follow-up study. men. The lipid research clinics mo

13 Sobolski JC, Kolesar JJ, Kornitzer MD, et al. Physical fitness does not reflect physical activity patterns in middleaged workers. Med Sci Sports Exerc 1988; 20: 6-13. 
14 Peters RK, Cady LD, Bischoff DP, Bernstein L, Pike MC. Physical fitness and subsequent myocardial infarction in healthy workers. JAMA 1983; 249: 3052-6.

15 Sobolski J, Kornitzer M, De Backer G, et al. Protection against ischemic heart disease in the Belgian fitness study: physical fitness rather than physical activity? $A m \quad \dot{f}$ physical fitness rather than
Epidemiol 1987; 125: 601-10.

16 Leon AS, Jacobs DR, De Backer G, Taylor HL. Relationship of physical characteristics and life habits to treadmill exercise capacity. Am $\mathcal{f}$ Epidemiol 1981; 113: 653-60.

17 Klissouras V, Pirnay F, Petit JM. Adaptation to maximal effort: genetics and age. 7 Appl Physiol 1973; 35: 288-93.

8 Slattery ML, Jacobs DR. Physical fitness and cardiovascular disease mortality. The US railroad study. Am $\mathcal{F}$ Epidemiol 1988; 127: 571-80.

19 Lie H, Mundall R, Erikssen J. Coronary risk factors and incidence of coronary death in relation to physical fitness. Seven-year follow-up study of middle-aged and elderly men. Eur Heart $\mathcal{f}$ 1985; 6: 147-57.

20 Thelle DS, Forde OH, Try K, Lehmann EH. The Tromsø Heart Study. Methods and main results of the crosssectional study. Acta Med Scand 1976; 200: 107-18.

21 Thelle DS, Arnesen E, Forde OH. The Troms Study. Does coffee raise serum cholesterol? $N$ Engl $₹$ Med 1983; 308: 1454-7.
22 Slatin B, Grimby G. Physiological analysis of middle-aged and old former atheletes. Circulation 1968; 38: 1104-15.

23 Wilhelmsen L, Tibblin G, Aurell M, Bjure J, Ekström-Jodal B, Grimby G. Physical activity, physical fitness and risk of B, Grimby G. Physical activity, physical fitness and 30

24 Bjartveit K, Foss OP, Gjervig T. The cardiovascular disease study in Norwegian counties. Results from first screening. study in Norwegian counties. Result

25 Holme I, Helgeland A, Hjermann I, Leren P, Lund-Larsen PG. Physical activity at work and at leisure in relation to coronary risk factors and social class. A 4-year mortality follow-up. The Oslo Study. Acta Med Scand 1981; 209. 277-83.

26 SAS Institute. SAS/STAT guide for personal computers. (version 6 edition.) Cary NC, USA: SAS Institute, 1987. 27 Hickey N, Mulcahy R, Bourke GJ, Graham J, Wilson-Davis $\mathrm{K}$. Study of coronary risk factors related to physical activity in 15171 men. BMF $1975 ; 3$ : 507-9.

28 Sonnenblick EH, Downing SE. Afterload as a primary determinant of ventricular performance. Am $\mathcal{F}$ Physiol 1963; 204: 604-10.

29 Cohn JN, Franciosa JA. Vasodilator therapy of cardiac failure. N Engl f Med 1977; 297: 27-31. 